\title{
ПОЛЯРИЗАТОРИ НА ОСНОВІ КВАДРАТНИХ ХВИЛЕВОДІВ ІЗ ДІАФРАГМАМИ
}

\author{
Биковський О. В. \\ (Науковий керівник Пільтяй С. I., к.т.н., доцент) \\ Начіональний технічний університет Украйни \\ «Київський політехнічний інститут імені Ігоря Сікорського», \\ Радіотехнічний факультет
}

Поляризатор — це мікрохвильовий пристрій, який виконує перетворення електромагнітних хвиль із ортогональними коловими поляризаціями у хвилі 3 ортогональними лінійними поляризаціями та навпаки [1]-[3]. Таке перетворення відбувається шляхом внесення диференційного фазового зсуву, близького до $90^{\circ}$, між модами хвилеводу з ортогональними поляризаціями. Поляризатор може бути розроблений i виготовлений на основі круглого, коаксіального або квадратного хвилеводів. Основною перевагою поляризатора iз діафрагмами над поляризаторами інших видів є можливість забезпечення найбільш широкосмугового режиму роботи із хорошими електромагнітними характеристики, які можна поліпшувати за рахунок збільшення кількості використаних у структурі діафрагм. Недоліком $\epsilon$ зростання довжини поляризатора, яке виникає у цьому випадку. Також поляризатори на основі діафрагм у хвилеводах є технологічними пристроями, оскільки вони можуть бути відносно просто виготовлені за допомогою високоточного фрезування двох однакових симетричних металевих деталей. Внутрішня структура типової конструкції поляризатора на основі квадратного хвилеводу з діафрагмами представлена на рис. 1.

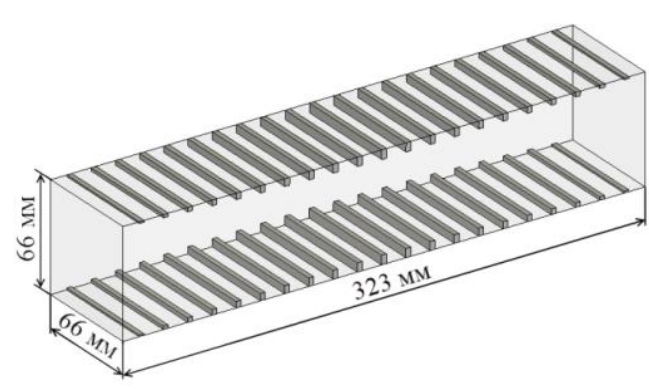

Рис. 1. Структура поляризатора на основі квадратного хвилеводу з діафрагмами

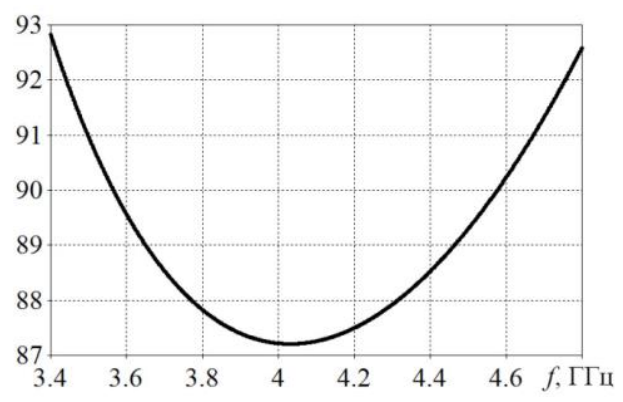

Рис. 2. Диференційний фазовий зсув поляризатора для діапазону $3,4-4,8$ ГГц

У розробленому в [1] поляризаторі за допомогою оптимізації конструкції було отримано диференційний зсув фаз між модами $\mathrm{TE}_{10}$ та $\mathrm{TE}_{01} 90^{\circ} \pm 3^{\circ}$ у межах розширеного С-діапазону частот 3,4-4,8 ГГц. Відповідна кросполяризаційна розв'язка $є$ вищою 30 дБ. Отриманий після оптимізації диференційний фазовий зсув показано на рис. 2.

Метод забезпечення потрібного диференційного фазового зсуву виключно за допомогою оптимізації розмірів діафрагм [2] має таку ж гнучкість розробки, 


\section{ІІІ ВНТК Радіоелектроніка у XXI столітті}

як і комбінований метод зі зміною поперечних розмірів хвилеводу [3]. Проте при комбінованому методі можна отримати менше відхилення диференційного фазового зсуву від $90^{\circ}$ при однакових поздовжніх розмірах або меншу довжину поляризатора при тому ж диференційному фазовому зсуві. Частину фазового зсуву вносять секції хвилеводу зі зміненими поперечними розмірами, тому необхідна кількість діафрагм у структурі поляризатора може бути зменшена.

На рис. 3 показано отримані в [2] виміряний (суцільна лінія) та розрахований (пунктирна крива) диференціальний фазовий зсув розробленого авторами поляризатора. Максимальне відхилення диференційного фазового зсуву від розрахованого становить $0,3^{\circ}$ і виникає на верхній частоті робочого діапазону 5,7-7,7 ГГц. Кросполяризаційну розв'язку представлено на рис. 4. Результати іï вимірювання за допомогою методу, запропонованого в [4], показано колами.

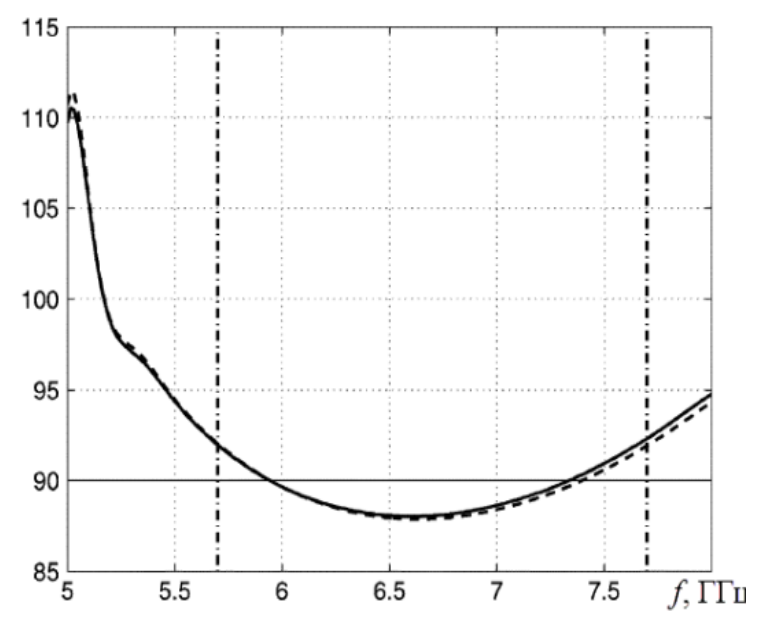

Рис. 3. Диференційний фазовий зсув поляризатора комбінованого типу

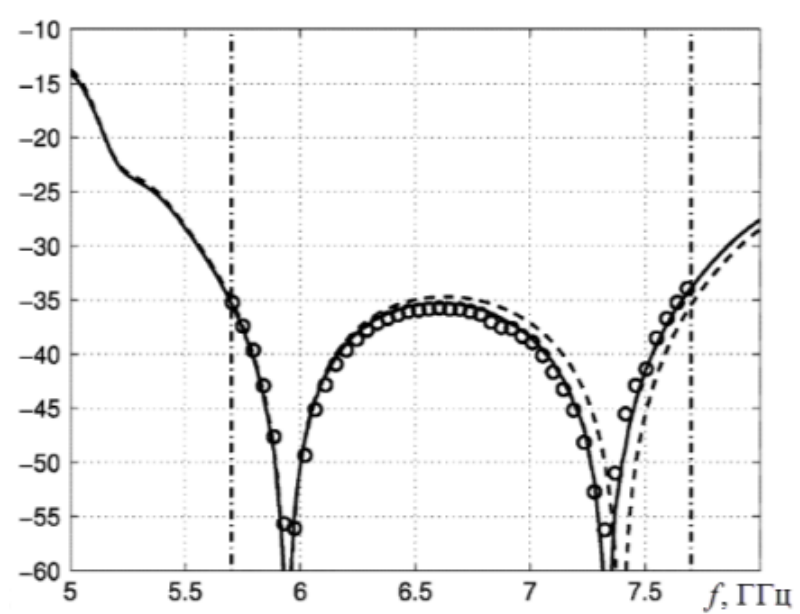

Рис 4. Кросполяризаційна розв'язка поляризатора для діапазону 5,7-7,7 ГГц

Отже, поляризатори на основі квадратних хвилеводів із діафрагмами забезпечують якісні електромагнітні характеристики у широких робочих діапазонах частот і можуть бути виготовлені за допомогою високоточного фрезування. Отже, вони є найефективнішими для застосування в сучасних супутникових інформаційних системах різного призначення.

\section{Література}

1. Piltyay S. I. High performance extended C-band $3.4-4.8 \mathrm{GHz}$ dual circular polarization feed system / S. I. Piltyay// Int. Conf. on Antenna Theory and Techniques, pp. 284-287, May 2017.

2. Virone G. Optimum-iris-set concept for waveguide polarizers / G. Virone, R. Tascone, O. A. Peverini, R. Orta // IEEE Microw. Wireless Compon. Lett., 2007.- Vol. 17, No. 3, pp. 202-204.

3. Virone G. Combined-phase-shift waveguide polarizer / G. Virone, R. Tascone, A. Peverini, etc // IEEE Microwave and Wireless Compon. Letters. - 2008. - Vol. 18, No. 8. - pp. 509-511.

4. Peverini O. A. A microwave measurement procedure for a full characterization of orthomode transducers / O. A. Peverini, R. Tascone, A. Olivieri, etc.// IEEE Transactions on Microwave Theory and Techniques. - 2003. - Vol. 51, No. 4. - pp. 1207-1213.

5. Пільтяй С.I. Інтегрований хвилевідний фазозсувач на основі індуктивних штирів / C.I. Пільтяй, А.В. Булашенко // Матеріали V Всеукр. наук.-метод. конференції, м. Шостка, 23 квітня 2020 року. - Суми: СДУ,2020. - С.82-83. 